ROCZNIKI PEDAGOGICZNE

Tom 12(48), numer $1-2020$

DOI: http://dx.doi.org/10.18290/rped20121-3

S. GABRIELA WISTUBA OP

\title{
CZYN I CIERPIENIE W SŁUŻBIE PRAWDY. SŁUGA BOŻY O. JACEK WORONIECKI NA UNIWERSYTECIE LUBELSKIM
}

\section{WSTĘP}

Adam Woroniecki (ur. w 1878) wstąpił do Zakonu Kaznodziejskiego w 1909 r. we Włoszech. Przyjmując habit, otrzymał imię Jacek, pod którym stał się powszechnie znany. Na początku 1914 r. został posłany do Krakowa z misją odnowy polskiej prowincji zakonu. Spędzając w krakowskim klasztorze lata wojny, poważnie chorował. $Z$ tego powodu jedynie w niewielkim stopniu mógł włączyć się $\mathrm{w}$ nauczanie teologii w studium zakonnym. Jego znajomi spoza zakonu byli przekonani, że kryje on w sobie ogromny potencjał, który trzeba wykorzystać dla dobra Kościoła. Ordynariusz krakowski, biskup Adam Sapieha wyszedł z propozycją, by o. Woroniecki został rektorem Wyższego Seminarium Duchownego. Otrzymał odmowną odpowiedź generała dominikanów, który nie zgodził się na objęcie przez o. Jacka tej funkcji ,ze względu na zadania, jakie w najbliższym czasie zamierza mu powierzyć w zakonie" (Theissling, 1918).

W tym samym czasie ks. Idzi Radziszewski zwrócił się do o. Woronieckiego z zaproszeniem do współtworzenia uniwersytetu katolickiego w Lublinie. Niemożność skontaktowania się z generałem zakonu w tym czasie spowodowała, że w porozumieniu z delegowanym na tereny Polski o. Piotrem Żaczkiem zdecydowano, by przyjąć propozycję (Karolewicz, 2000). Dnia 21.03.1919 r. o. Jacek przybył do Lublina, a 25.03. wygłosił wykład inauguracyjny. Rozpoczął się dziesięcioletni intensywny okres zaangażowania

S. dr Gabriela Wistuba OP - adres do korespondencji: ul. Sienkiewicza 49, 05-220 Zielonka; e-mail: gabriela.wistuba@dominikanki-misjonarki.org. 
o. Woronieckiego na KUL. Ciągle jednak pojawiały się propozycje innych ważnych funkcji, jak np. objęcia biskupstwa w Gnieźnie czy w Warszawie (Ratti, 1995). Woroniecki konsekwentnie prosił, by mu ich nie powierzano ze względu na potrzeby nowo utworzonej uczelni. Jednocześnie poważną przeszkodą w energicznym działaniu dla rozwoju lubelskiej wszechnicy był słaby stan jego zdrowia.

\section{ZAANGAŻOWANIE W PIERWSZYCH LATACH ISTNIENIA UNIWERSYTETU}

Na Uniwersytecie Lubelskim (UL - taka była nazwa uczelni do 1928 r.) o. Woroniecki podjął następujące funkcje: profesor zwyczajny teologii moralnej (1919-1929), wykładowca etyki na Wydziale Prawa i Wydziale Humanistycznym (1920-23), metodyki religii (1923/24) i pedagogiki (1924/25), prodziekan Wydziału Prawa Kanonicznego (1920/21) i Wydziału Teologicznego (1921/22) (Stanowski, 1969). Pierwsze lata pracy o. Woronieckiego na UL zaowocowały licznymi publikacjami. Nie poprzestał jednak na działalności naukowej i dydaktycznej. Od początku obecności w Lublinie zaangażował się w duszpasterstwo. Szybko stał się duchowym przywódcą Stowarzyszenia Młodzieży Akademickiej „Odrodzenie”. Pomagał studentom tworzyć struktury organizacji, podpowiadał, jak przeprowadzać spotkania, podsuwał lektury. Prowadził dla nich rekolekcje, uczestniczył w wyjazdach, mobilizował do podejmowania szerokiej działalności społecznej (Stowarzyszenie, 1923-29). Rozwijający się w Europie ruch skautowy również znalazł w nim zdecydowanego propagatora. Włączył się w jego przeszczepianie na grunt polski, wierny idei pedagogicznej, według której pierwszym wychowawcą dla wychowanka jest jego środowisko - „pedagog zbiorowy”. Zdaniem o. Woronieckiego ten element oddziaływania wychowawczego jest mocno akcentowany w harcerstwie i trafnie realizowany. Dominikanin więc chętnie przebywał z harcerską bracią, prowadził gawędy, publikował artykuły pomocne w pracy wychowawczej i propagujące ten ruch. Wkrótce stanął na czele Zarządu Oddziału Lubelskiego Związku Harcerstwa Polskiego (Związek Harcerstwa Polskiego, 1921).

Studia na lubelskiej uczelni umożliwiały zdobycie wykształcenia teologicznego kapłanom. Ojcu Jackowi powierzono zadanie kierownika konwiktu dla księży studiujących. Niektórzy z nich pozostawili wspomnienia ilustrujące niemal zakonny tryb życia w konwikcie, ale także życzliwość i troskę 
opiekuna. Okazuje się, że nie wszystko odbywało się łatwo i bezkonfliktowo, jak można wyczytać z upomnienia biskupa lubelskiego, nakazującego o. Woronieckiemu ogłosić mieszkańcom konwiktu, że obowiązują ich pod karą suspensy przepisy prawa kanonicznego. Sprawa dotyczyła zakazu „spowiadania niewiast poza konfesjonałem” oraz obowiązku „noszenia stroju duchownego" (Fulman, 1920).

\section{WOJNA 1920 ROKU}

W 1920 r. byt rozwijającej się uczelni, tak jak powstającego po latach zaborów państwa polskiego, został nagle zagrożony inwazją bolszewicką. Ojciec Woroniecki bez wahania włączył się w działania obronne. Własnym wysiłkiem przyczyniał się do podtrzymania na duchu ludności, a swój autorytet wykorzystał, by uchronić przed zniechęceniem i rezygnacją z walki. Zgłosił gotowość posługi jako kapelan lotny Wojska Polskiego (Dokumenty osobiste o. J. Woronieckiego, s. 91). Stanął na czele Wydziału Kwalifikacyjnego Wojewódzkiego Komitetu Obrony Narodowej (Wojewódzki Komitet, 1920), zajmującego się przydzielaniem zadań ludności cywilnej, takich jak zdobywanie funduszy, organizowanie aprowizacji, pomoc ofiarom. Zapamiętano, że razem $\mathrm{z}$ harcerzami, $\mathrm{z}$ łopatą $\mathrm{w}$ ręku, brał udział $\mathrm{w}$ budowaniu okopów (Błeszyńska, 2006, s. 109).

O sytuacji uniwersytetu w Lublinie podczas wojny 1920 r. dowiadujemy się pośrednio z listów o. Czesława Lacrampe OP, wykładowcy dogmatyki. Podkreśla on zarazem znaczenie lubelskiej uczelni, jakie miała w świadomości kadry profesorskiej. W listopadzie 1920 r. pisał do przełożonego w Rzymie:

[...] trzeba było za wszelką cenę powrócić do Polski, przynajmniej żeby odnaleźć nasze książki i pomoce, które inwazja bolszewicka rozproszyła na cztery strony świata... Dzieło przedsięwzięte w Polsce jest istotne w całej oczywistości. Ten naród umieszczony między protestantyzmem a prawosławiem - musi zostać katolicki i Kościół musi poczynić wszelkie wysiłki, żeby to utrzymać i promować... (Lacrampe, 5.11.1920).

Mówiłem o Lublinie i interesach tego uniwersytetu [...] Ojciec zna konieczność fundacji tego rodzaju, jedynej katolickiej między prawosławiem a protestantyzmem; w kraju, który w imieniu katolicyzmu przeciwstawia się bolszewizmowi zagrażającemu najazdem całej Europie [...] Książki i manuskrypty uniwersytet i Dom Francuski ewakuowały do Częstochowy i gdzie indziej, na odległość $100 \mathrm{~km}$, w wielkim bałaganie (Lacrampe, 22.11.1920). 
Również w tym czasie o. Woroniecki był brany pod uwagę jako kandydat na biskupa tworzącej się diecezji w Łodzi. Prosił o interwencję, by taka decyzja nie została podjęta, uzasadniając, że odejście z uniwersytetu osłabiłoby jeszcze bardziej siły młodej uczelni (Lacrampe, 20.04 .1921 i 6.05.1921).

\section{WYBÓR NASTĘPCY KS. I. RADZISZEWSKIEGO}

W lutym 1922 r. zmarł ks. Idzi Radziszewski. Episkopat Polski, którego własnością był wówczas uniwersytet w Lublinie, stanął przed koniecznością szybkiego znalezienia osoby zdolnej utrzymać go w kryzysowej sytuacji, której szczegóły są mało znane. Dlatego warto przytoczyć fragmenty wypowiedzi biskupów:

Na dokonanie koniecznych przeróbek i odnowienie gmachów potrzeba $200 \mathrm{mln}$ marek. Wydatkowano dotąd $30 \mathrm{mln}$, w kasie na ten cel jest $30 \mathrm{mln}$ [...] Na wydatki bieżące kasa uniwersytetu nie rozporządza żadnymi funduszami. Minister Wyznań Religijnych i Oświecenia Publicznego nie zatwierdził jeszcze statutu uniwersytetu, nie wniósł też wniosku do Sejmu o przyznanie praw uniwersytetowi [...] Po zmarłym Rektorze śp. Księdzu Prałacie Idzim Radziszewskim, niewyczerpanym w zabiegach około dźwignięcia i zorganizowania uniwersytetu, niezrażającym się żadnemi trudnościami, zasłużonym na polu naukowem, oddanym całym sercem młodzieży i przez tę młodzież kochanym [...] na czele uniwersytetu powinien stanąć mąż wielkiej nauki, niezwykłych zdolności organizacyjnych, całkowicie oddany sprawie uniwersytetu i młodzieży (Protokół, 22-24.03.1922, AKr 14).

Zwrócono się do ordynariuszy z prośbą o wskazanie kandydatów na stanowisko rektora UL. Wśród nadesłanych odpowiedzi powtarza się nazwisko o. Woronieckiego, zawsze jednak z zastrzeżeniem „o ile mu zdrowie pozwoli”. Jednocześnie pisma te ujawniają opinię, jaką cieszył się powszechnie o. Jacek: „człowiek nauki, a przy tym dobrze widziany w kołach, które dotychczas łożyły na uniwersytet” (Bilczewski, 24.02.1922), „człowiek nauki i niewyczerpanej energii, który ma nadto stosunki rozległe" (Matulewicz, 3.03.1922). Wspomniane znajomości, a także wykształcenie i obycie w świecie, mające swe źródło zapewne w fakcie pochodzenia ze starego arystokratycznego rodu, skoligaconego z całym środowiskiem ziemiańskim, stały się nie tylko osobistym bogactwem kandydata na rektora, ale dawały nadzieję na większe możliwości w kierowaniu uniwersytetem. Ojciec Woroniecki napisał wówczas do generała zakonu: 
Uniwersytet Lubelski poniósł wielką stratę po śmierci ks. Radziszewskiego, swojego pierwszego rektora i założyciela. Poszukujemy kogoś, kto go zastąpi. Biskup lubelski poinformował mnie, że moja osoba jest poważnie brana pod uwagę [...] Przeciw mojej kandydaturze jest najpierw moje zdrowie, dość złe ostatnio. Dalej: obowiązki rektora pochłonęłyby wszystkie moje siły [...] W końcu - możemy się dobrze zastanowić, czy uniwersytet zyska na tym, ponieważ nie mam umiejętności organizacji i zarządzania. Jedynym powodem «za» byłaby dobra sytuacja, którą mam w kraju, dobre relacje z Episkopatem, z Rządem, z uniwersytetami państwowymi, w końcu $-\mathrm{z}$ rodzinami bogatymi, zdolnymi wspierać nasz uniwersytet. Obecnie trwam w «świętej obojętności», chociaż raczej na «nie», obawiając się wysiłku, jaki należałoby włożyć [...] (Woroniecki, 12.03.1922).

Stan zdrowia o. Woronieckiego w tym czasie stawiał pod znakiem zapytania nie tylko możliwość objęcia rektorstwa, ale nawet kontynuowania nauczania. Jeszcze na początku lutego 1922 r. pisał do zaprzyjaźnionego zgromadzenia zakonnego:

\begin{abstract}
dowiedziałem się, że zacny Wasz Kapelan Ks. Prałat Siewierski przeniósł się do wieczności [...] Bardzo bym pragnął wiedzieć, czy macie już Kapelana na jego miejsce i czy ja bym się Wam na to miejsce nie nadał. Będąc u Was w zeszłym roku [...] przychodziło mi już wtedy na myśl, że na stare lata byłoby to dobre stanowisko dla mnie. Niestety na te stare lata nie potrzebowałem długo czekać, bo oto siły tak mnie opadły tu, iż trudno mi będzie nadal obowiązki profesora Uniwersytetu spełniać [...] (Woroniecki, 7.02.1922, AFC).
\end{abstract}

Gdy zatem ważyła się jego kandydatura na stanowisko rektora, zawiadomił pisemnie, że nie może podjąć takiej odpowiedzialności (Protokół, 2526.04.1922, AAL). Mimo to biskupi zgromadzeni na konferencji plenarnej powierzyli mu to zadanie: „Zjazd postanowił jednogłośnie kandydaturę Ojca Jacka na stanowisko rektora uniwersytetu w Lublinie" (Protokół, 21-25. 06.1922, AKr 15; Karolewicz, 2000). Wysłuchano zainteresowanego, który wyraził przekonanie, że nie powinien obejmować tej funkcji, po czym postanowiono prosić Piusa XI o zatwierdzenie tej kandydatury oraz porozumieć się z Senatem uczelni i generałem zakonu dominikanów. Biskupi podjęli zarazem zobowiązanie wspierania uniwersytetu.

\title{
OJCIEC JACEK WORONIECKI \\ - REKTOR UNIWERSYTETU LUBELSKIEGO
}

Chociaż nowo wybrany rektor ponawiał prośby o zwolnienie go $\mathrm{z}$ tej funkcji, decyzja nie została zmieniona (Protokół, 26-28.09.1922, AKr 17). 
Ze świadomością wagi zadania i własnych nieproporcjonalnych możliwości zbierał siły i pomysły, aby podołać powierzonej misji. W jego notatnikach intencji odprawianych mszy św. pojawiają się regularne zapisy „Pro Universitate Lub.”. Sprawował je jako wotywne o Najświętszym Sercu Jezusa, szczególnie w pierwsze piątki miesiąca (Woroniecki, 1906-1949).

Od początku kierowania uniwersytetem główną troską było zabezpieczenie środków materialnych koniecznych do funkcjonowania uczelni. Ojciec Jacek okazał się niestrudzonym w pomysłach kwestarzem i roztropnym konstruktorem stałych dochodów. W praktyce efekty podjętych zabiegów były krótkotrwałe $\mathrm{z}$ powodu kryzysu gospodarczego i ogromnej dewaluacji w państwie. Przyjrzyjmy się inicjatywom rektora dla ratowania uczelni.

Ojciec Woroniecki szukał darczyńców wszędzie - na pierwszym miejscu pośród warstwy ziemiańskiej, poczytującej sobie ochronę kultury i rozwój narodu za swój obowiązek. W celu uzyskania pomocy docierał do znajomych rodzin, spotykając się z ich przedstawicielami bądź prowadząc korespondencję. Latem 1923 r. napisał ok. 800 listów w sprawach finansowych UL - do osób prywatnych, instytucji, urzędów (Błeszyńska, 2006). $\mathrm{Z}$ relacji jednego z profesorów przebywającego na wakacjach dowiadujemy się, że żadne progi nie były za wysokie, aby udać się z prośbą o wsparcie uczelni:

[...] otrzymałem list o. Woronieckiego, nowego rektora UL. Prosi mnie usilnie, żebym pojechał do Rzymu zanim wrócę do Lublina, i żebym podczas audiencji u Ojca Świętego: 1) poprosił Jego Świątobliwość, aby zechciał skierować do biskupów polskich list polecający na rzecz uniwersytetu; 2) poprosił Jego Świątobliwość i otrzymał z jego hojności zapomogę dla UL, który z powodu obecnych trudności przechodzi poważny kryzys finansowy [...] (Lacrampe, 31.08.1922).

Finansowanie uniwersytetu $\mathrm{z}$ jednorazowych wpłat ofiarodawców, do których kieruje się indywidualną prośbę, nie mogło jednak stanowić źródła jego utrzymania na dłuższą metę. Ojciec Jacek doszedł do przekonania, że podstawą bytu uczelni musi się stać ofiarność całego społeczeństwa i to na sposób regularnego wpływu zadeklarowanych kwot. W tym celu w grudniu 1922 r. założył Towarzystwo Uniwersytetu Lubelskiego (Statut, 1922; Karolewicz, 2000). Zachęcał do wpisywania się na jego członków biskupów, duchownych (Woroniecki, 1923, Odezwa) i wszystkich wiernych, a także wzywał, by szeroko propagować jego ideę.

Uniwersytet Lubelski, jako jedyna katolicka uczelnia wyższa, stanowił własność Kościoła w Polsce. Stąd kluczowe sprawy musiały być ustalane z Episkopatem. Ojciec Woroniecki wykorzystał ten fakt, przedstawiając 
coraz nowe prośby i uzyskując aprobatę wielu inicjatyw. Już w czerwcu 1922 r. biskupi postanowili „dawać siły profesorskie, o które UL poprosi”, w diecezjach „ustanowić komitety popierania moralnego i materialnego" uniwersytetu oraz ogłosić składkę na UL we wszystkich kościołach Polski (Protokół, 21-25.06.1922, AKr 15). Podczas następnych zjazdów podejmowano kolejne środki, aby uniknąć wciąż grożącej abdykacji rektora. Ustanowiono mu pomocników - ds. naukowych i materialnych. Powołana została Rada Towarzystwa UL, w skład której wchodził prymas i czterech biskupów. Do ordynariuszów wystosowano prośbę, by w każdym roku wyznaczyli dzień świąteczny, kiedy taca będzie przeznaczona na uniwersytet w Lublinie (Protokó1, 26-28.09.1922, AKr 17) oraz by zawiadamiali „rektora uniwersytetu o liczniejszych zjazdach duchowieństwa lub świeckich w diecezji, aby rektor uniwersytetu lub jego delegat mógł przybyć na Zjazd w celu zachęcania do popierania sprawy uniwersytetu" (Protokół, 24-27.06.1923, AKr 22). Postanowiono wyznaczyć diecezjalnych kolektorów składek, aby usprawnić ich przesyłanie w warunkach ogromnej dewaluacji (Fulman, 1923).

Coraz pilniejsza stawała się rozbudowa gmachów uczelni, której nie mogły już pomieścić stare pokoszarowe budynki. Rektor zainicjował fundowanie sal wykładowych przez zamożne rodziny lub środowiska. Jedną z pierwszych była sala im. Henryka Sienkiewicza, zasponsorowana przez Roztworowskich (Woroniecki, 1923, Przemówienie). Episkopat ufundował salę Piusa XI (Protokół, 9-10.02.1923, AKr 19, 22). Wkrótce znalazło się wielu fundatorów kolejnych pomieszczeń (Kronika, 1923).

Starania o. Woronieckiego o materialny byt uczelni podsumowano później słowami: „utrzymał Uniwersytet w najcięższym czasie” (Szymański, 1924). Natomiast wspomnienia studentów przechowały obraz rektora przede wszystkim jako wspaniałego wykładowcy i bliskiego, troskliwego duszpasterza. „Był to wybitny tomista i profesor teologii [...], głosił budujące kazania [...], organizował rekolekcje wielkopostne” (Mystkowski, 1978); „Ceniliśmy wykłady z etyki o. Woronieckiego. Były nie tylko mądre i ciekawie podane, ale też często okraszane humorem i dowcipem, tak dla niego właściwym" (Grzegorzewska, 1978). Pomimo nawału zajęć o. Woroniecki znajdował czas na posługę duchową. Regularnie spowiadał wielu penitentów i podejmował się kierownictwa duchowego (Ciechanowska, Czartoryski, Pokorna). Pod względem intelektualno-moralnym formował Stowarzyszenie Młodzieży Akademickiej „Odrodzenie” (Stowarzyszenie), głosił rekolekcje, pisał listy do proszących o radę. 
W okresie swego rektoratu o. Woroniecki nie zaprzestał pracy naukowej. Opublikował kilkanaście opracowań (książek i artykułów) oraz liczne przedmowy, przemówienia, recenzje, thumaczenia. Ogrom pracy mocno nadszarpnął jego siły. W ciągu niecałych dwóch lat przewodzenia lubelskiej uczelni oprócz „zwyczajnego" zmagania się z wagotonią - nieraz dziesięć dni w miesiącu nie mógł normalnie pracować - i częstych przeziębień przeszedł poważną operację. Hospitalizacje zajęły łącznie blisko trzy miesiące (Fulman, 1924, Woroniecki, 1917, 1922-1924, 24.02.1924). Jesienią 1923 r. rektor nie był w stanie wypełniać swych codziennych obowiązków, stąd na uczelni zaczął panować chaos administracyjny. Sytuację pogarszał kryzys ekonomiczny w kraju. Z powodu ogromnej dewaluacji profesorowie nie otrzymywali wynagrodzenia. Ojciec Woroniecki już w grudniu zapowiedział swą rezygnację (Woroniecki, 14.12.1923). Miesiąc później kanclerz uniwersytetu udzielił mu urlopu zdrowotnego (Fulman, 1924), a w marcu $1924 \mathrm{r}$. Episkopat przyjął jego prośbę o zwolnienie z funkcji rektora (Protokół, 21.03.1924, AKr 24).

Ciekawy szczegół rzuca światło na pojmowanie przez o. Woronieckiego swej roli jako rektora i na rezultaty, jakie udało mu się osiągnąć:

\footnotetext{
W czerwcu 1925 r. na uroczystym posiedzeniu Senatu z udziałem Rady Biskupiej ds. Uniwersytetu o. Jacek Woroniecki otrzymał pozwolenie na postawienie własnym kosztem, na pamiątkę swego rektoratu, posągu Matki Boskiej na dziedzińcu uniwersytetu. W roku następnym figura ta nadeszła do Lublina i ustawiona została na małym dziedzińcu, przylegającym do kościoła, gdzie dotąd stoi (Wojtkowski, 1969).
}

Fakt ten w połączeniu z zapisami znanymi z różnych dokumentów wskazuje, że ojciec Jacek zaangażował dla lubelskiej uczelni nie tylko wszystkie swe ludzkie siły i umiejętności, ale też łączył je z duchowym przeżywaniem własnego powołania jako służby Bogu, ojczyźnie, ludziom.

\section{DALSZA POSŁUGA NA UL}

Po złożeniu urzędu rektora o. Woroniecki pozostał na lubelskiej uczelni jako wykładowca i dziekan Wydziału Teologicznego (1924-29). W roku akademickim 1928/29 pełnił dodatkowo funkcję wicerektora. Niezależnie od zadań wynikających z zatrudnienia wiele czasu poświęcał młodzieży, osobom konsekrowanym, przedstawicielom inteligencji i wszystkim potrzebującym jako duszpasterz, kierownik duchowy, rekolekcjonista: 
prowadził wykłady religijne dla świeckich studentów (o misjach), odprawiał nabożeństwa z nauką, przewodniczył zebraniom dyskusyjnym «Odrodzenia»; oprócz przedmiotów teologicznych wykładał etykę na Wydziale Humanistycznym (Szymański, 1925).

W tym też czasie z jego posługi kierownictwa duchowego korzystały osoby, z którymi rozważał założenie w Polsce nowej wspólnoty zakonnej o celu misyjnym i katechetyczno-apostolskim. Współpraca ta zaowocowała powstaniem Zgromadzenia Sióstr Dominikanek Misjonarek Jezusa i Maryi.

Realizując zadania nauczyciela akademickiego, a zarazem własne powołanie, o. Woroniecki kontynuował pracę naukową i pisarską. W tym czasie opublikował ponad 40 pozycji, w tym 7 książek, liczne artykuły, a także przedmowy i recenzje. Wygłaszał odczyty na zjazdach różnych organizacji, brał czynny udział w konferencjach naukowych i debatach publicznych (Wistuba, 2011). Na Międzynarodowym Kongresie Eucharystycznym w Chicago w 1926 r. przedstawił zagadnienie doniosłości wychowawczej liturgii eucharystycznej oraz zapoznał słuchaczy z „sytuacją Kościoła na Syberii”, czyli prześladowaniami stosowanymi przez władzę sowiecką (Donovan, 1927).

Trudno w skrócie przedstawić wszystkie owoce, jakie dzięki szerokiej działalności o. Jacka Woronieckiego w czasie pracy na KUL stały się dziedzictwem narodu, kultury i nauki, Kościoła w Polsce, wreszcie - poszczególnych osób. Uczelnia lubelska w wielkim stopniu jemu zawdzięcza swój późniejszy rozwój, zwłaszcza szkoły filozoficznej i myśli pedagogiczno-etycznej, których fundamenty tkwią w tomistycznym sposobie dyskursu naukowego konsekwentnie przez niego wprowadzanym na grunt polski (Grzybowski, 2007; Mazur, 2019; Polak, 2011; Wistuba, 2011).

Podczas dziesięciu lat pobytu w Lublinie o. Woroniecki podejmował starania o powrót dominikanów do ich klasztoru w tym mieście, z którego zostali wygnani przez rosyjskiego zaborcę po powstaniu styczniowym. Nie zapomniał również o powierzonym mu zadaniu odnowienia polskiej prowincji zakonu, chociaż ze względu na zaabsorbowanie sprawami uczelni mógł angażować się w to dzieło tylko w ograniczonym zakresie (Woroniecki, 192225; 1926-29).

Przedstawienie roli, jaką o. Woroniecki wypełnił wobec lubelskiej wszechnicy, nie byłoby kompletne, gdyby pominąć jeszcze jedną rzeczywistość, mocno wpisaną w jego posługę: poniesione w tym czasie cierpienie. Przyjmowanie z rąk Bożej opatrzności wszystkiego, co zsyła, także niemocy, choroby i upokorzeń, z wewnętrzną zgodą - zakonnik ten uczynił własną ofiarą, swoim wkładem $\mathrm{w}$ powierzoną misję. Oceniając z punktu widzenia zasad 
duchowości, ascetyki i mistyki, być może właśnie poniesionym cierpieniom w największym stopniu zawdzięczał on trwałość owoców podejmowanych trudów: utrzymanie uczelni w fazie początkowych kryzysów i jej późniejszy rozwój. Cierpienia te były różnej natury, zarówno fizyczne, jak i duchowe: prócz chorób, o których była już mowa, a do których dołączyły się następne - brak klasztoru i wspólnoty zakonnej, ciągłe zagrożenie istnienia uczelni i troska o zapewnienie jej utrzymania, wycofywanie się studentów szukających lepszych warunków bytowych, w pewnym okresie rywalizacja w gronie profesorskim, odmienne poglądy na metodę naukową i dydaktykę. Zmagania te zostały wyrażone w memoriale przeciw likwidacji UL, którego współautorem był o. Woroniecki (Memoriał, 1927).

Ojciec Woroniecki zakończył pracę na Uniwersytecie Katolickim w Lublinie latem 1929 r. Wskutek reorganizacji Wydziału Teologicznego został zwolniony wraz z innymi profesorami (Fulman, 1929). Otrzymał wprawdzie informację, że jest pierwszym na liście, których zamierzano zatrudnić na nowo, ale nie chcąc samemu decydować w tej sytuacji, odniósł się do generała zakonu, który przeniósł go do Rzymu, do pracy w Papieskim Uniwersytecie św. Tomasza z Akwinu Angelicum.

\section{PROCES BEATYFIKACYJNY}

Ojciec Jacek Woroniecki zmarł 18.05.1949 r. w krakowskim klasztorze dominikanów, w opinii świętości. Został pochowany w Krakowie na Cmentarzu Rakowickim, ale po kilku latach jego ciało przeniesiono do Warszawy, do odbudowanego kościoła św. Jacka. Rozpoczęto zbieranie o nim wspomnień i świadectw przekonania o łaskach otrzymanych za jego wstawiennictwem. Jego pamięci poświęcano miejsca - tablice, sale oraz wydarzenia konferencje naukowe, spotkania modlitewne. Nieustannie wznawiane są publikacje jego dzieł, powstają prace naukowe analizujące jego nauczanie.

Proces beatyfikacyjny rozpoczął się w Krakowie 7.12.2004 r. Zostali przesłuchani świadkowie życia Sługi Bożego. Cenzorzy teologowie przebadali wszystkie jego pisma publikowane. Komisja Historyczna na podstawie dokumentów odnalezionych w kwerendach archiwalnych opracowała relację o jego życiu i osobowości. Rozwija się oddolnie jego kult: wierni pielgrzymują do jego grobu, modlą się o potrzebne łaski, prosząc o jego beatyfikację, odprawiają nowenny przez jego wstawiennictwo. Zbierana jest 
dokumentacja dotycząca domniemanych cudów. Obecnie trwa thumaczenie akt procesowych.

Lubelski okres życia o. Jacka Woronieckiego to niemały etap realizowania przez niego własnego powołania, czyli zmagania w zdobywaniu świętości. Wierne pełnienie woli Boga przez konkretnego człowieka zawsze owocuje dobrem dla innych, niejako ściąga na ziemię łaski przeznaczone do otrzymania przez jego zaangażowanie $\mathrm{i}$ w ten sposób przyczynia się do budowania Kościoła i całej społeczności ludzkiej. Katolicki Uniwersytet Lubelski zawdzięcza o. Jackowi Woronieckiemu nie tylko przetrwanie na początku swego istnienia, nadanie profilu pracy naukowej i zabezpieczenie form utrzymania przez dziesięciolecia, ale - ufamy - również i dzisiaj czerpie duchowe moce w służbie Prawdy z dziedzictwa, jakie Sługa Boży pozostawił temu miejscu i dziełu przez swój czyn i cierpienie.

\section{BIBLIOGRAFIA}

$$
\text { ŹRÓDŁA ARCHIWALNE }
$$

Kraków: Archiwum Kurii Metropolitalnej Krakowskiej (AKr):

Protokoły obrad Komitetu Biskupów i zjazdów Biskupów Polskich (1922-1924), sygn. TS XIII/14, 15, 17, 19, 22, 24.

Theissling, L. (1918). List do A. Sapiehy - 9.10.1918, sygn. TS XXXVIII / 174 [Dodatek do teki XVII].

Kraków: Archiwum Polskiej Prowincji Dominikanów:

Czartoryski, M. List do ks. W. Korniłowicza - 8.10.1926, sygn. S3/6.

Dokumenty osobiste o. Jacka Woronieckiego: metryka urodzenia, dowody osobiste, paszporty, świadectwa, stopnie naukowe i inne, sygn. S39/1.

Lublin: Archiwum Archidiecezjalne Lubelskie (AAL):

Bilczewski J., List do Biskupa Lubelskiego - 24.02.1922., sygn. Rep.61 VIII 1.

Fulman, M.:

- (1920). Do Dyrektora Konwiktu teologów w Lublinie - 13.03.1920, sygn. Rep.61 VIII 1;

- (1923). Odezwa do ordynariuszów - 19.09.1923, sygn. Rep.61 VIII 1;

- (1924). Pismo do o. J. Woronieckiego - 14.01.1924, sygn. Rep.61 VIII 1;

- (1929). Pismo do profesorów Wydziału Teologicznego KUL - 28.05.1929, sygn. Rep.61 VIII 2.

Matulewicz, J. List do Biskupa Lubelskiego - 3.03.1922, sygn. Rep.61 VIII 1.

Memoriał dziekanów przeciw likwidacji UL - 5.05.1927, sygn. Rep.61 VIII 1.

Protokół zebrania Komitetu Biskupów w Warszawie (1922), sygn. Rep.61 I 1.

Statut Towarzystwa Uniwersytetu Lubelskiego (1922), sygn. Rep.61 VIII 1. 
Szymański, A.:

- (1924). List do Biskupa Lubelskiego - 24.03.1924, sygn. Rep.61 VIII 1.

- (1925). Sprawozdanie z działalności UL w r. 1924/25, sygn. Rep.61 VIII 1.

Woroniecki, J.:

- (1923). Odezwa „Do Duchowieństwa Polskiego”, sygn. Rep.61 VIII 1.

- (1923). List do Biskupa Lubelskiego - 14.12.1923, sygn. Rep.61 VIII 1.

Lublin: Archiwum Państwowe w Lublinie:

Wojewódzki Komitet Obrony Narodowej w Lublinie (1920-1921), sygn. 428 / 1, 2, $27,31$.

Związek Harcerstwa Polskiego - Zarząd Oddział w Lublinie (1921-1930), sygn. 410 / 1427.

Rzym: Ordo Fratrum Praedicatorum - Archivum Generale:

Lacrampe, C. Listy do Generała Zakonu, sygn. XIII.87098.

Woroniecki, J. (1922-1925; 1926-29). Listy do Generała Zakonu, sygn. XIII.87098; 87132.

Szymanów: Archiwum Główne Sióstr Niepokalanek w Szymanowie:

Woroniecki, J. (1917-1928). Listy do s. Gertrudy Skórzewskiej, sygn. P 126.1.XI.

Warszawa: Archiwum Archidiecezji Warszawskiej:

Stowarzyszenie Młodzieży Akademickiej „Odrodzenie” (1923-29), sygn. M.I.3: 14, 16, 17, 20, 22-25, A.X.3.79.

Warszawa: Archiwum Zgromadzenia Sióstr Franciszkanek od Cierpiących:

Woroniecki, J. (1922). List do przełożonej Franciszkanek od Cierpiących (AFC), sygn. s.C II, T. I 13 / M. Magdalena.

Zielonka: Archiwum Zgromadzenia Sióstr Dominikanek Misjonarek Jezusa i Maryi:

Ciechanowska, M. Mój życiorys, sygn. IA/45 nr 10.1.

Pokorna, A. Wspomnienie o Ojcu Jacku, sygn. II /4331.

Woroniecki, J.:

- (1906-1949). Intencje mszalne, sygn. II/0121.

- (1924). List do Janiny Wielowieyskiej - 24.02.1924, sygn. II /3132.

ŹRÓDŁA PUBLIKOWANE

Donovan, C.F. (red.) (1927). The story of The Twenty-Eighth International Eucharistic Congress held at Chicago, Illinois, United Tates of America from June 20-24, 1926. Chicago: The Committee in Charge at Chicago of the XXVIII International Eucharistic Congress.

Grzegorzewska, E. (1978). Wspomnienie. W: G. KAROLEWICZ (red.), Katolicki Uniwersytet Lubelski we wspomnieniach pierwszych studentów z lat 1918-1925 (s. 93-98). Lublin: Towarzystwo Naukowe KUL.

KAROLEwicZ, G. (2000). Źródła dotyczące Jacka Woronieckiego OP w archiwach lubelskich. W: J. GaŁKowski, M.L. Niedziela (red.), Człowiek - moralność - wychowanie. Życie i myśl Jacka Woronieckiego OP (s. 23-35). Lublin: Towarzystwo Naukowe KUL.

Kronika Towarzystwa (1923). Wiadomości Towarzystwa Uniwersytetu Lubelskiego, 37.

MystKowsKi, S. (1978). Wspomnienie. W: G. KAROLEWICZ (red.), Katolicki Uniwersytet Lubelski we wspomnieniach pierwszych studentów z lat 1918-1925 (s. 41-45). Lublin: Towarzystwo Naukowe KUL. 
RATTI, A. (1995). List do Kard. P. Gasparri'ego - 11.09.1919 i 5.11.1919. W: S. WiLK (red.), Acta Nuntiaturae Polonae, t. 57, vol. 6 (s. 203-204) i vol. 7 (s. 23). Romae: Inst. Historicum Polonicum.

Woroniecki, J. (1923). Przemówienie na inauguracji Sali im. H. Sienkiewicza. Wiadomości Towarzystwa Uniwersytetu Lubelskiego, 21-26.

\section{OPRACOWANIA}

BŁeSZYŃSKA, I.Z. (2006). O. Jacek Woroniecki, dominikanin - wychowawca-patriota, 1878-1949. Lublin: Fundacja Servire Veritati Instytut Edukacji Narodowej.

GrZYBOwSKI, J. (2007). O. Jacek Woroniecki OP - prekursor myśli tomistycznej w Polsce. Studia Plockie, 35, 151-158.

Mazur, P.S., Kiereś, B., Skrzyniarz, R., PŁazińsKa, A. (2019). Jacek Woroniecki. Kraków: Wydawnictwo Naukowe Akademii Ignatianum.

PolaK, R. (2011). Woroniecki Jacek Adam. W: A. MARYNIARCZYK (red.), Encyklopedia filozofii polskiej, t. 2: M-Ż (s. 838-841). Lublin: Polskie Towarzystwo Tomasza z Akwinu.

StanowsKi, A. (1969). Spis wykładowców 1918-1939. W: M. Rechowicz (red.), Księga Jubileuszowa 50-lecia Katolickiego Uniwersytetu Lubelskiego (s. 105-118). Lublin: Towarzystwo Naukowe KUL.

Wistuba, G. (2011). Prowadzić ku Zbawcy. Duszpasterstwo w nauczaniu i postudze o. Jacka Woronieckiego OP. Sandomierz: Wydawnictwo Diecezjalne i Drukarnia w Sandomierzu.

WoJtKowski, A. (1969). Katolicki Uniwersytet Lubelski 1918-1944. W: M. RECHOwicz (red.), Księga Jubileuszowa 50-lecia Katolickiego Uniwersytetu Lubelskiego (s. 21-104). Lublin: Towarzystwo Naukowe KUL.

\section{CZYN I CIERPIENIE W SŁUŻBIE PRAWDY. SŁUGA BOŻY O. JACEK WORONIECKI NA UNIWERSYTECIE LUBELSKIM}

\section{STRESZCZENIE}

Sługę Bożego o. Jacka Woronieckiego związało z uczelnią lubelską dziesięć lat życia. Były to lata bardzo aktywnego i wszechstronnego zaangażowania. Zostawiły trwałe owoce $\mathrm{w}$ istnieniu i kształcie uniwersytetu, ale nie mniejsze, a może bardziej podstawowe - w jego osobowości, w jego świętości. Ojciec Woroniecki pełnił tu obowiązki wykładowcy, naukowca, pracownika administracji, a równocześnie duszpasterza: młodzieży akademickiej, kapłanów studiujących, powołań, osób konsekrowanych, harcerzy, mieszkańców miasta. Jako rektor zasłużył się skutecznymi wysiłkami w przekonywaniu Episkopatu i społeczności wiernych w Polsce o niezwykłym znaczeniu uniwersytetu zarówno dla niepodległej ojczyzny, jak i dla Kościoła powszechnego. Ustanowił trwałe struktury zdobywania środków finansowych na utrzymanie uczelni i podjął trud jej rozbudowania w wyjątkowo niesprzyjających warunkach gospodarczych kraju. Jako autorytet moralny wskazywał kierunki zaangażowania i podtrzymywał nadzieję w społeczeństwie polskim. Nie był jednak aktywistą, działaczem na zewnątrz. Poświęcając siły ducha i ciała uczelni, kształtował także siebie. Dziś trwa jego proces beatyfikacyjny. Heroiczny trud lubelskiej działalności zakonnika potwierdzają liczne dokumenty, dzieła oraz świadectwa pozostawione przez współpracowników i wychowanków.

Słowa kluczowe: Jacek Woroniecki; uniwersytet; Katolicki Uniwersytet Lubelski; pedagogika; kierownictwo duchowe. 


\title{
ACTION AND SUFFERING IN THE SERVICE OF TRUTH \\ - SERVANT OF GOD FATHER HIACYNTH WORONIECKI AT THE UNIVERSITY OF LUBLIN
}

\begin{abstract}
SUMMARY
Servant of God Father Hiacynth Woroniecki was associated with the University of Lublin for ten years. During that period, he undertook an extraordinary active and many sided engagement which resulted in permanent influence on the existence and shape of the institution; That time had also similar or even fundamental impact on Fr. Woroniecki's personality and sanctity. The Dominican assumed the duties of lecturer, scientist, administration worker. At the same time, he was taking pastoral care of students, studying priests, consecrated persons, scouts, city citizens and as a vocation director. As a rector he succeeded in convincing the Episcopate and the Polish faithful of the University's extraordinary significance for both the independent Country and the Catholic Church. He established methods of gaining funds for the maintenance of the University and also took the trouble to carry out its expansion under exceptionally difficult economic circumstances. As a moral authority, he indicated the right direction of engagement and he sustained the hope in the Polish society. However, he was not an activist, nor did he work much outside. While devoting his spirit's and body's powers in favour of the university, he was shaping himself too. Nowadays his beatification process is under way. Fr. Woroniecki's heroic effort of the Lublin period is evidenced by numerous documents left by his co-workers and pupils.
\end{abstract}

Key words: Hiacynth Woroniecki; university; University of Lublin; pedagogy; spiritual direction. 